\title{
Fetishizing Dialogue and Commodifying Peacemaking
}

\section{Mahdi Tourage}

\begin{abstract}
This paper assesses the ongoing dialogue and student exchange between the Mennonite Central Committee (MCC) and one of the most violent institutions in Iran, the Imam Khomeini Education and Research Institute (IKERI). I will use this relationship between the MCC and IKERI to examine the broader question of interreligious transnational dialogue and peacemaking.

After a brief background of this somewhat "secretive" dialogue/ student exchange, I will evaluate its effects. Of particular interest will be the following questions: How do we responsibly shape Muslim-non-Muslim dialogue for peace and understanding in a global context that is inevitably shaped by an imbalance of power and representation? How are the acts of resistance undertaken by the disenfranchised local/diasporic Iranian communities and the sustained systematic violence against them impacted by a peaceful faith community such as the Mennonites? How does the absolutization of "dialogue" coupled with self-proclaimed theological mandates effectively strip away the archives of violence from living memories and histories? What can examining the decade-long dialogue between the MCC and IKERI reveal about the mechanisms of perpetuation and dissimulation of imperial domination and control? How can transnational interreligious interventions be the nexus for infusing sensitivity and expecting accountability?

I argue that a fetishization of dialogue and a commodification of peacemaking took place between the MCC and IKERI, resulting in the patronage of the sign systems of existing normative ideologies of violence. ${ }^{1}$
\end{abstract}

\footnotetext{
Mahdi Tourage, Ph.D. (2005, University of Toronto) is a visiting assistant professor of Islamic studies and classical Persian literature, Department of Near Eastern Studies, University of Michigan, Ann Arbor, and book review editor, American Journal of Islamic Social Sciences. He is the author of Rumi and the Hermeneutics of Eroticism (Brill: 2007) and is interested in Islamic religious thought and Sufism, classical Persian literature, gender, and postmodern theories. His articles have appeared in Comparative Studies of South Asia, Africa, and the Middle East, and Iranian Studies.
} 


\section{Background}

The Mennonites Central Committee's (MCC) involvement in Iran began with its relief efforts in the aftermath of the devastating 1990 earthquake and continued with the subsequent influx of more than one million Iraqi refugees from the first Gulf war. ${ }^{2}$ The goal was to promote more interaction, particularly in the form of a student exchange program similar to the one that had been successfully tried with Eastern Europe during the cold war. The MCC was introduced to the Qum-based Imam Khomeini Education and Research Institute (IKERI) through contact with Iran's permanent mission to the United Nations in New York. Two IKERI students arrived at Regis College of the Toronto School of Theology (affiliated with the University of Toronto) in 1998 and 1999. One has since completed his doctorate and returned.

The idea is explained as follows: This student exchange program allows Mennonites to live and study among the people of Iran, while their Iranian counterparts live among the Mennonites of Toronto. Ed Martin writes: "By living together and studying each other's religions, North American Mennonites and Iranian Muslims are able to better understand and respect each other and to become friends." ${ }^{3}$ This relationship continued with a few conferences in Iran and Canada: in Toronto, "Muslims, Christians, and the Challenges of Modernity" (2002); in Qum, "Revelation and Authority" (2004); and in Waterloo, "Spirituality" (2007). The 2007 conference at Conrad Grebel University College was met with peaceful protest by expatriate Afghans and Iranians. As a result, its scheduled public meetings were cancelled. ${ }^{4}$

\section{Ayatollah Mesbah-Yazdi}

To understand what is wrong with IKERI, we must look at its founder and chief: Ayatollah Mesbah-Yazdi. ${ }^{5}$ Hardly any aspect of this institute is not directly influenced and dependent upon the person of Mesbah-Yazdi. In his recent study of the Shi i revival, Vali Nasr points out that Mesbah-Yazdi is the most powerful and the most conservative member of the clergy in Iran today. ${ }^{6}$ $\mathrm{He}$ is not considered to be very learned by his own peers. A more learned and comparatively moderate clergy, Ayatollah Yousef Sanei, is quoted as saying: "[Ayatollah Mesbah-Yazdi] was never respected by the founders of Islamic Republic, and ... his authority was not based on religious knowledge but on political power he had acquired since Khomeini's death." Mesbah-Yazdi is best known for a "fascist reading of Islam," which includes "outrageous declarations, including religious support for physical violence against anyone who dared seek alternative readings of the faith," ${ }^{8}$ and his violent views are no secret. For example, his own website relates his support for suicide bomb- 
ings (also known as "martyrdom operations") as permissible, even sometimes obligatory:

It is regrettable that the propaganda of the enemies of Islam has influenced the Muslim Ummah so much that Muslims, instead of planning for the uprooting of the Zionist regime and its arrogant supporters, have occupied themselves with questioning and discussing the legitimacy of the Palestinians' self-defense, which is carried out under the most oppressive conditions imaginable. For sure, when protecting Islam and the Muslim Ummah depends on martyrdom operations, it not only is allowed, but even is an obligation (wajib) as many of the Shi 'ah great scholars and Maraje', including Ayatullah Safi Golpayegani and Ayatullah Fazel Lankarani, have clearly announced in their fatwas. ${ }^{9}$

When Mesbah-Yazdi is asked about the legitimacy of suicide bombing against Israeli civilians, he answers:

Muslims should not attack those civilians of the occupied territories who have announced their opposition to their government's vicious crimes, except for situations in which they are used as human shields and fighting the aggressors depends on attacking those civilians. ${ }^{10}$

He has a documented anti-democratic track record of uttering statements like: "It doesn't matter what the people think, they are ignorant sheep." It is no surprise that in one of his speeches posted on his website, he defends the amputation of hands and stoning to death of "criminals" as issues that are out of the debate about human rights. ${ }^{12}$ Along the same lines, and contrary to the opinion of some Muslim scholars who argue that social circumstances enforced slavery upon Islam, MesbahYazdi holds: "If there is a war between us and the infidels, we will take slaves. The rule of slavery is not abrogated and is eternal; we will take slaves, will bring them to the Islamic world and keep them with the Muslims, guide them, make them Muslims, and then will return them to their own countries." ${ }^{13}$ What about differences in interpretation? The ayatollah opines: "If anyone tells you he has a different interpretation of Islam, sock him in the mouth." 14

This violent opposition to a multiplicity of interpretations of Islam, antithetical to the Shi i tradition of ijtihad (independent legal reasoning) and the historical independence of Shi i scholars, has made his absolutist position a subject of public ridicule. Playing on the similarity between the words mesbah and temsah (Persian "crocodile"), a political cartoonist depicted him as a crying crocodile choking a journalist with his tail. In the political context 
of the time, everyone understood who the crocodile represented. Riotous demonstrations by the hardliners ensued, and the journalist was jailed..$^{15}$

Within Iran's complex power structure, Ayatollah Mesbah-Yazdi holds the position of "the chief ideologue of the conservative establishment." ${ }^{16}$ This position, the most important one in Iran's informal power structure, consists of a handful of clergy whose associations go back to pre-revolutionary times. ${ }^{17}$ This close-knit powerhouse controls the Leader's house, the judiciary, the Revolutionary Guards, and, most importantly, the Intelligence Ministry. According to Wilfried Buchta, religious justification in the form of secret fatwas (independent religious edicts/opinions) for the assassination of dissidents by death squads - later connected to the Intelligence Ministry as part of a larger effort to depose the reformer President Khatami - came from Mesbah-Yazdi and four other ayatollahs. ${ }^{18}$

After the violent backlash against the student uprising in the summer of 1999, when then-President Khatami was denouncing violence as inimical to the rule of law and proper functioning of a civil society, Mesbah-Yazdi's speech at Tehran's Friday prayer condoned and, even encouraged the violence: "The taboo that says every act of violence is ipso facto bad must be broken, ... the enemies of Islam must feel the harsh and violent hand of Islam." ${ }^{19}$ He encouraged the Revolutionary Guards, irregulars, and vigilantes to "stop agitation for change by any means." ${ }^{20}$ As Nasr puts it: "While many Iranians yearned for a democratic future, Mesbah-Yazdi was looking to the Taliban for his." ${ }^{21}$

It is interesting to note that Mesbah-Yazdi's cultivation and promotion of intolerance and violence is not based upon jurisprudence or theology, for which he is apparently ill-equipped. The Iranian philosopher Abdolkarim Soroush has pointed out that Mesbah-Yazdi's violent position is mostly rooted in "the fascistic philosophies and philosophers as well." ${ }^{22} \mathrm{He}$ argues that Mesbah-Yazdi's violent positions are influenced by Ahmad Fardid (d. 1994), an Iranian secular philosopher who promoted disdain for the West based upon his uncritical acceptance of the German philosopher Martin Heidegger's philosophy. ${ }^{23}$ In this context, the possible link between fostering and promoting a militant reinterpretation of traditional Shi'i Islam by Mesbah-Yazdi ${ }^{24}$ and Heidegger's underdeveloped idea of the possibility of synthesizing eastern civilization and western philosophy is worth noting. ${ }^{25}$ Perhaps in the context of the Third Reich and the Second World War, Heidegger's philosophical musing of this possibility was hinting at a militarypolitical alliance of Nazi Germany with "the East," whoever that might be (e.g., Hindus, Buddhists, Muslims, Arabs, or Persians). ${ }^{26}$ 
What is germane to the goals of this paper, however, is that in light of Heidegger's well-known Nazi party affiliation we can detect more than a hint of coincidental accord between his philosophy and the exceedingly violent anti-Jewish rhetoric of such ideologues as Mesbah-Yazdi and his followers, the most prominent of them being Iran's current president: Mahmood Ahmadinejad. ${ }^{27}$ Soroush himself, while not uncritical of the West, calls the promotion of hatred and violence toward it by the likes of Mesbah-Yazdi, and particularly their violent anti-Jewish rhetoric, a "disease." ${ }^{28}$ More importantly he notes that exposing this "disease" and those who are afflicted with it is "an obligation, particularly now that some of these [people] are in positions of power." ${ }^{29}$

\section{Structural and Functional Problems with this Dialogue}

So, one may ask, why would a most peaceful faith community like the Mennonites engage in a long-term dialogue and student exchange with a mafialike organization run by a violently intolerant petty scholar like MesbahYazdi? This question is best answered by the Mennonites themselves. For the purpose of this paper, however, I will use this relationship to explore the effects of this transnational interreligious dialogue on both structural and functional levels.

It should be noted at the outset that this is not a dismissal of dialogue, even with a powerfully violent man like Mesbah-Yazdi, for "even a stopped clock is correct twice a day." ${ }^{30}$ After all, the actual world is made up not only of pluralists and inclusivists, who are already convinced of the need for dialogue, but also of exclusivists. In fact, not including the extremists and exclusivists could translate into an intolerance of the religious "others." In this context, Peter Donovan has gone so far as to argue that "unshakable conservatism may well be far better placed than fallibilist liberals to engage effectively in practical co-operation with those holding different beliefs because there is no question of the parties involved being expected to reconsider their deepest traditional convictions and commitments." 31

On a structural level, the most obvious issue overlooked in the MCCIKERI dialogue is the historical and political context in which it takes place. This decontextualized setting is particularly significant in a neoimperialist context in which many parts of the western world still thrive on paternalistically disciplining and parenting other "juvenile" nations. ${ }^{32}$ This decontextualized approach to dialogue is closely related to the concept of transnational "bordercrossings." ${ }_{33}$ Articulated by feminist scholars in the 
context of transnational-global feminist discourse on "third world" 34 subjects, the problematic of bordercrossing could be extended beyond the cultural similarities and differences to include translational interreligious exchange as well.

Hence, a theological issue formulated and deployed in one culture loses its historically and culturally specific context necessary for the understanding of its full and concrete impact on human lives as it "crosses" borders. ${ }^{35}$ For example, consider comments by Hassan Rahimpour, one of the representatives of IKERI (recorded in the 2002 Toronto conference entitled: "The Positive and Negative Challenges of Modernity for Iranian Shi i Muslims and North American Mennonites Christians"):

Although Islam has an optimistic view of humanity, it does not separate rights from responsibility, morality from economics, the world from the afterlife, religion from government. It is through earthly government and law that religious morality is established. ${ }^{36}$

First of all, this is a radical/modernist departure from the "traditional" Shi i view, which overwhelmingly rejects the legitimacy of any earthly government, including that of the Shi $i$ jurists, in the absence of the Infallible Imam. ${ }^{37}$ It also makes essentialist claims that are always left unchecked in a Muslim-Christian dialogue. C. M. Naim writes that in a dialogue, Christians often fail to question Muslims' claims that Islam is a total way of life encompassing all worldly and otherworldly matters. These claims implicitly endorse totalizing views of "true" or "pure" Islam; in this case, such a claim justifies the totalitarian nature of the Iranian regime..$^{38}$

More important for the objectives of this paper is the culminating last sentence, which presents the establishment of religious morality (which is argued to be inseparable from economics and citizens' rights and responsibilities) is presented as the government's function. We can deconstruct this statement, show its fallacy in the context of Shi i political theory, agree with it, or dismiss it as the product of a modernist militant interpretation of Shi i Islam. What we should not do, however, is lose sight of the oppressive ideological structuration that produces this statement and, in turn, is reinscribed by it.

In the context of the Islamic Republic of Iran, this statement is reiterated to theologically legitimate the structure of a brutal totalitarian power, the day-to-day survival of which is contingent upon blatant human rights abuses, imprisonment, torture, and killing. Lest we forget, open disagreement with this very statement in today's Iran carries severe consequences. However, as it crosses the geographical/political and theological "borders" 
and is uttered in the safety of a private academic conference at a western university, it comes across as the result of an innocently naïve misinterpretation of textual/historical sources and remains unchallenged.

This leads us to consider the intrinsic functional dissonance of this dialogue. Absent is a vigilantly self-critical approach to the historical and political situatedness of the Mennonites' decade-old dialogue project. In all of the literature that either discusses or refers to this dialogue, there is no mention of the abhorrent human rights records of the Iranian counterpart or how/if the Mennonites ever plan to address it. In fact, recent attempts by the Iranian diasporic community, some of whom are victims of the violence committed by this very organization, to question the group during their visit to Canada have been blocked by the invitees. ${ }^{39}$

Furthermore, the courteous terms of the dialogue have prevented an examination, let alone an interrogation, of the violence perpetrated by IKERI and its impact upon the lives of Iranian people even by the host party. ${ }^{40}$ In a moment of confounded ambivalence reflecting on one conference held in Toronto, A. James Reimer, at that time director of the Toronto Mennonite Theological Centre, refers to serious differences between the two groups and expresses regret that "forbearance," perhaps "too much" of it, prevented the "tough issues," like the "violation of human rights both in western and Arab countries," from being addressed. ${ }^{41}$ As may be expected, IKERI has exploited its ties with a humanitarian peaceful religious organization (the MCC) to bolster its prestige and legitimacy within the political confines of Iran.

The decontextualization of dialogue produced by what I call "protective bordercrossings" obfuscates, oversimplifies, or simply overlooks differences and similarities between the two religious organizations. On the one hand, information that affirms the "otherness," "difference," and "exoticness" of other cultures crosses borders and becomes "iconic" and "representative." ${ }^{42}$ It is along these lines that the Mennonites' literature refers to the deceptively small but powerful and dangerous institution of IKERI with such overdetermined phrases as "Iranian Shi i Muslims," giving the impression that somehow this institution is representative of all Iranian Shi i Muslims. ${ }^{43}$ On the other hand, this protective bordercrossing permits erroneous categorical oversimplifications. An example of this can be found in Reimer's words referring to the Mennonites and IKERI as "two religious minority groups." ${ }^{44}$ I am not sure about the "religious minority" status of Mennonites, but it is irresponsibly dangerous to minimize the unofficial and official state resources and capabilities at the disposal of the powerhouse ruled by Ayatollah Mesbah-Yazdi. ${ }^{45}$ 
Oversimplification is also found in encounters with the complexity of the Iranian political/religious context. For example, Thomas Finger (scholar in residence, Bethany Seminary, Richmond, IN) reports on his personal experiences during his two visits to Iran to present a "Christian perspective" at the "Mahdi Conferences" (2006 and 2007). He also participated in meetings with Ahmadinejad. He asks:

Why, then, were my discussions so lengthy, and my partners apparently so curious and sincere? Why was I free to say whatever I wished? Why were so many Christian books being translated into Farsi, and so many in various languages available at the Khomeini Institute? ${ }^{46}$

These questions would have been best answered by those in Iran who are struggling for democracy, freedom of expression, human rights, feminism, and pluralism. Finger's sober exposition rightly points out that dialogue is a necessary alternative to demonization and admits that Ahmadinejad's government was possibly using him to create the impression of intellectual and religious freedom. However, oversimplification leads Finger to miss the many cultural, political, and religious clues to Iran's totalitarian regime. For example, he minimizes the importance of Ahmadinejad's statement about "wiping Israel off the map" by writing:

Regarding Israel, Ahmadinejad used a Farsi expression routinely but questionably translated as "wipe off the map." It is clear to me that he means removing the name "Israel" from literal maps, as has happened with "USSR." ${ }^{47}$

I would argue that again it is irresponsibly dangerous to oversimplify the propensity of such totalitarian regimes for violence and to overlook the actual acts of oppression committed by them. This danger is particularly acute when considering Ahmadinejad's nuclear ambitions in the context of his distorted vision of a Shi i messianic imperative. ${ }^{48}$

The use of the terms Ayatollah, Shi i, imam, Iran, Khomeini, Muslims, and others in MCC literature is sufficient to portray this institute as a stereotypical representative of the Iranian brand of Shi i Islam. Surely the line of thought promoted by IKERI can be recognized as a strand of modernist Shi i discourse. But the problem is not entirely one of false representation; rather, the problem with this oversimplification is that it denies the play of differences. The tension between the recognition of some similarity ("we are both religious minorities with valid theological points of views") and difference ("we do not agree on the most fundamental issues such as the use of violence to impose morality") is resolved by what has been articulated as 
disavowal within the anti-colonial discourse. ${ }^{49}$ Disavowal is formulated as a mode of defense whereby the subject refuses to recognize "the reality of a traumatic perception. ${ }^{\prime 50}$ What the Mennonite party disavows in this dialogical relationship is essentially the anti-dialogical, undemocratic, and violently intolerant nature of Mesbah-Yazdi and his organization. It is this disavowal that characterizes the MCC's positions of "fixity" ${ }^{1}$ as in, for example, erroneously viewing IKERI as a religious minority group or maintaining dialogue only with this institute. Homi Bhabha's insight is particularly relevant here:

The stereotype is not a simplification because it is a false representation of a given reality. It is a simplification because it is an arrested, fixated form of representation that, in denying the play of difference (which the negation through the Other permits), constitutes a problem for the representation of the subject in significations of psychic and social relations. ${ }^{52}$

The full impact of this disavowal could best be felt if the MCC ever tries to reach out to true religious minorities in Iran, for example, to the persecuted Bahai community. It is not surprising that this dialogue has remained limited to abstract topics such as "From Instrumental Reason to Sacred Intellect." ${ }^{33}$ Can we imagine an open dialogue with IKERI on, for example, the struggles or rights of gays and lesbians in Iran? Without this disavowal and its concomitant disconcerting silence on "tough issues" (and, by necessity, silencing the dissident voices at the 2007 Waterloo conference), the dialogue with Mesbah-Yazdi's organization would not have lasted this long.

Disavowal could also be extended to the MCC's implicit unconsciousness of its own historical location and epistemological coordinates. That is to say, regardless of its self-perception and in spite of its undoubtedly best intentions, the MCC's mission to Iran bears similarities to the western colonial project, which believes that under certain conditions the "natives" can be reformed, even proselytized. Residues of the "White Man's Burden" syndrome is evident in individual Mennonite cases. For example, Jewel Showalter describes her mission's goal, along with her husband in the Middle East (1982-89), as

sharing the gospel in culturally sensitive ways that, ... would result in the formation of reproducing fellowships of believers among persons, most of whom had never even met a Christian, and most certainly had never heard of the gospel. ${ }^{54}$

If we allow that the MCC's disavowal is at least partly about mystifying their own location along the colonial continuum, then perhaps the function 
of protective bordercrossing is also to safeguard the MCC. In other words, the MCC's disavowal of its self-protective bordercrossing brings its members close to the amnesia affecting the western humanist tradition, which erases the West's role in creating the discourse of "imperialist knowledgemaking and power-taking." ${ }^{55}$

Aside from the problematic of this decade-long dialogue's somewhat secretive nature, a concrete example of this power-taking can be found in the silencing of dissident voices during the last MCC-IKERI conference at the University of Waterloo in 2007. Prior to this event, a group of CanadianIranian academics, human rights activists, journalists, and victims of torture and violence of the Iranian regime met with MCC representatives in Waterloo to explain their objections to the terms of this conference. ${ }^{56}$ The Iranian participants spoke of the heavy toll that confronting the Iranian regime and the likes of Mesbah-Yazdi has taken on people's lives both inside and outside of Iran. In a moving gesture, they showed scars of physical and psychological torture and trauma and pleaded with the Mennonites not to protect these "criminals" from criticism while in Canada. The participants left the meeting disempowered and further wounded when the Mennonites present listened patiently and attentively and yet insisted that their "theological mandate" to dialogue supersedes all other concerns. ${ }^{57}$

In this context, where the recognition of differences (between the two religious organizations) and similarities (between this Mennonite group's dialogical project and colonial discourse) is disavowed by a rigid fixation on a specific form of dialogue, we can speak of a fetishization of dialogue. The term fetish first came into widespread use during the eighteenth century in the context of the inanimate objects worshipped by so-called "primitive" people. Sigmund Freud argued that something of the disavowal (simultaneous acknowledgement and denial of a given reality, often a traumatic reality) is always preserved in the formation of a fetish. ${ }^{58}$ Karl Marx used this term to describe how social relations in capitalist societies assume the illusory form of relations between things, hence his term commodity fetishism. ${ }^{59}$ Georg Lukàcs' reworked version of commodity fetishism as a theory of representation is an apt conceptual tool for unpacking another layer of this dialogical relationship. He writes that commodity fetishism occurs when a "relation between people takes on the character of a thing," when it becomes so "all-embracing as to conceal every trace of its fundamental nature." ${ }^{\circ 0}$

The "fundamental nature" of the odd MCC-IKERI relationship is not easy to pin down. Susan Kennel Harrison, coordinator of the MCC-IKERI 
student exchange program at the Toronto School of Theology from its beginning until 2007, asks:

Outside and inside the Mennonite community there has been a desire to provide a clear label for what this exchange program is. Is it an inter-faith dialogue? Is it an academic dialogue? Shall we call it a theological dialogue? Is it more adequately represented in the phrase "a dialogue of life"? Is it peace-making? Bridge-building between nations? ${ }^{\text {?1 }}$

She goes on to answer that "it is all of these and more." Why, after more than ten years of close contact, is it so hard to point to the fundamental nature of this relationship? The answer must be sought in the mutation (Lukàcs would say "concealment") of that fundamental nature in the process of disavowal and reified fetishization discussed above. Residues of that fundamental nature (for example, the MCC's sincere - if naïve - intentions) are still present in the disavowal and can surely be recovered. At this point, however, it is irrelevant what the nature of this exchange program may have been; even less relevant is what ostentatious "label" we can provide for it.

What is relevant is this dialogue's effect on the lived experiences of human beings. The MCC-IKERI relationship turns out to be a commodity fetish with an intrinsic value in and for itself that overlooks all other concerns. One example of such a concern related to the functional purpose of dialogue is the absence of any measurable positive transformation in the lives of those most negatively affected by IKERI's violence. Dialogue with only one particular institution in Iran will necessarily result in an exclusivist mode of knowledge production..$^{62}$ The MCC's fixation on this exclusivist, decontextualized, and transnational relationship has stripped away the acts of resistance by all of those who are excluded from this dialogue, both inside and outside of the Islamic Republic of Iran. Furthermore, it has erased the archives of violence perpetrated or supported by IKERI.

\section{Conclusion}

In conclusion, we must ask: "How do we responsibly shape Muslim-nonMuslim dialogue in a global context so that instead of patronizing the sign systems of existing ideologies of violence, this undertaking can demystify the mechanisms of disavowal?" By no means exhaustive, here are some suggestions:

1. To begin with, dialogue cannot be an end in itself, for this would lead it to become fetishized beyond recognition. 
2. Once the fetishization of dialogue is recognized, a process of defetishization must occur. Among other things, defetishization involves the ethics of contingency that underscore the relational and contextual nature of any dialogue and help to avoid positions of fixity. Thus, instead of a recurrent disavowal, "multiple entryways" into the other's culture can be explored. ${ }^{63}$ We should be uneasy that in spite of admitted difficulties in tabling human rights violations in this ongoing dialogue, and in spite of the presence of many disenfranchised Iranian NGOs, charities, human rights organizations, and individual activists desperate for resources and global connection with like-minded people, the MCC's only dialogue partner during the past decade happens to be the most powerful and violent mafia-style organization in the Islamic Republic of Iran. ${ }^{64}$

3. A dialogue like the one between the MCC and IKERI could be contextualized by mobilizing sensitivity and accountability to the human costs involved. Once trust is established through a process of mutual enrichment, no genuine issue of concern should be off limits. Therefore, instead of the commodifying and fetishizing that overdetermines the value of dialogue, that value should be measured according to the meaningful possibilities for positive personal, social, and political transformation. Needless to say, this transformation is best appreciated in the real lives of the millions who are terrorized by the Iranian regime through its unofficial instruments of terror (e.g., IKERI) and those disempowered by the terms of this dialogue. Otherwise, there are plenty of self-congratulatory testimonies of the positive effects on those directly involved in this isolative mode of exclusivist dialogue. ${ }^{65}$ Indeed we walk dangerous ground when we acquiesce to polite silences on "tough issues," explicitly shirking accountability and ignoring the human cost of dialogue with an oppressive institution.

4. The ethics of contingency also demand that a transnational interreligious dialogue begin and end with a rigorous self-reflexivity of how our (e.g., the West and the MCC) self-articulations and transnational interventions are complicit in oppressive power relations. The awareness of our own historical location and a vigilant self-critique of our epistemological coordinates could circumvent the possibility of dialogue becoming an unwitting collaborator in sustaining the Iranian regime's violent ideologies. Self-reflexivity also allows for identifying how dialogue with the "other" refracts our own cultural biases and oppressions so that internal group struggles with class, gender, race, and sexuality are not swept aside in the name of interreligious, transnational dialogue. 


\section{Endnotes}

1. A shorter version of this paper was presented at the Fourth Annual Canadian Regional Conference of the Association of Muslim Social Scientists of North America (AMSS) entitled: "Imperialist Wars and Liberal Peace," November 1, 2008. I would like to thank Sonja Adrianovska and Gul Joya Jafri for their editorial assistance and helpful suggestions.

2. Ed Martin, "MCC and Iran," Mennonite Central Committee, Peace Office Publication 31, no. 3 (2001): 1-2.

3. Ibid., 3 .

4. See Mirko Petricevic, "Protest Shuts Down Clerics' Visit: Toronto and Regional Police Gather at UW in Case of Trouble," The Record, May 29, 2007.

5. For the background of IKERI's establishment, see www.roozonline.com/ archives/2007/02/002354.php, accessed January 15, 2009.

6. Vali Nasr, The Shia Revival: How Conflicts within Islam Will Shape the Future (New York: W. W. Norton, 2007), 216.

7. Geneive Abdo and Jonathan Lyons, Answering Only to God: Faith and Freedom in Twenty-First-Century Iran (New York: Holt Paperbacks, 2004), 39. Not so incidentally perhaps, Ayatollah Yousef Sanei is a comparatively moderate member of the clergy. For example, he condemns indiscriminate acts of violence, such as suicide bombings, in the strongest terms: "They [suicide bombers] are at the pit of hell." See his interview with CNN, February 6, 2007.

8. Ibid., 39; Reza Afshari, Human Rights in Iran: The Abuse of Cultural Relativism (Philadelphia: University of Pennsylvania Press, Pennsylvania in Human Rights, 2001), 213.

9. See www.mesbahyazdi.org/english/contact-us/afq/contact4.htm, accessed January 15, 2009 (original translation).

10. Ibid.

11. Afshin Molavi, The Soul of Iran: A Nation's Journey to Freedom (New York: W. W. Norton, 2005), 105.

12. See www.mesbahyazdi.org/, accessed January 15, 2009.

13. Nasr, The Shia Revival, 216.

14. Abdo and Lyons, Answering Only to God, 12.

15. For an informative discussion of these events, see Elton L. Daniel, The History of Iran (Abingdon, UK: Greenwood Press, 2000), 244-46; also see Abdo and Lyons, Answering Only to God, 39-40. The journalist has since fled Iran.

16. Ayatollah Yousef Sanei quoted in Abdo and Lyons, Answering Only to God, 35.

17. For an informative discussion of this informal power structure, see Wilfried Buchta, Who Rules Iran? The Structure of Power in the Islamic Republic (Washington, DC: Washington Institute for Near East Policy, 2001).

18. Ibid., 161-69. The number of these political assassinations was officially set at six; unofficially, however, between 150-200 deaths have been attributed to these death squads. For the struggle between the reformists and the hardliners 
to control the Intelligence Ministry, see Dariush Zahedi, Iranian Revolution Then and Now: Indicators of Regime Instability (Boulder: Westview Press, 2001).

19. Ibid., 184. A similar statement is found on Mesbah-Yazdi's own website, www.mesbahyazdi.org/, accessed January 15, 2009. An alternative translation of this statement reads: "This shameful stain that some think violence does not exist in Islam must be cleansed. We want and are resolute and decided to prove and show that violence exists at the heart of Islam." Quoted on Abdolkarim Soroush's website www.drsoroush.com/Persian/Interviews/P-INT-13841218HomaTV.html, accessed January 15, 2009 (my translation).

20. Nasr, The Shia Revival, 216.

21. Ibid.

22. Online at www.drsoroush.com/Persian/Interviews/P-INT-13841218-Homa TV.html, accessed January 15, 2009.

23. Fardid did not leave many written works behind. A website dedicated to him provides valuable links to his thoughts and secondary literature in various languages: www.ahmadfardid.com/, accessed January 15, 2009. For an informative discussion of how different western philosophical works (e.g., Martin Heidegger, Jurgen Habermas, Hannah Arendt, Isaiah Berlin, and Karl Popper) are read by Iranian intellectuals today, see Danny Postel, Reading Legitimation Crisis in Tehran: Iran and the Future of Liberalism (Chicago: Prickly Paradigm Press, 2006).

24. This particular reading of Shi ism does not originate from Mesbah-Yazdi; rather, it is a paradoxical synthesis of Marxism, existentialism, Heideggerianism, and a militant reinterpretation of traditional Shì i Islam most successfully employed by Ayatollah Khomeini. See Mehrzad Boroujerdi, Iranian Intellectuals and the West (Syracuse: Syracuse University Press, 1996).

25. It should be noted that in all likelihood Mesbah-Yazdi has never read anything by Heidegger; however, he has never criticized the Iranian Heideggerian camp either. Nevertheless, the genealogy of his thoughts can be linked to Heidegger. See Soroush's discussion of this at www.drsoroush.com/Persian/Interviews/ PINT-13841218-HomaTV.html, accessed January 15, 2009.

26. For a discussion of the relationship between Heidegger's philosophy and Nazism, see William V. Spanos, "Heidegger, Nazism, and the Repressive Hypothesis: The American Appropriation of the Question," Boundary 2, 17.2 (1990): 199-280.

27. This may partly explain the context of Ahmadinejad's denial of the holocaust and his infamous 2006 Tehran conference on this issue. Ayatollah MesbahYazdi was the only cleric who published a fatwa supporting Ahmadinejad during Iran's 2005 presidential election. Nasr writes: "After the election [Mesbah-Yazdi] declared that Iran now had its first time Islamic government and there was no need for any more elections." See Nasr, The Shia Revival, 216. 
28. Soroush leaves no doubt that he is speaking of Mahmood Ahmadinejad and his anti-Jewish threats of annihilating Israel. See www.drsoroush.com/Persian/ Interviews/P-INT-13841218-HomaTV.html, accessed January 15, 2009.

29. In this sentence, still referring to Ahmadinejad, Soroush uses faridah (obligatory), the most emphatic Arabic term from Islamic jurisprudence, in the sense of a religious duty. See ibid.

30. Gloria Steinem, commenting on Ahmadinejad's September 2007 talk at Columbia University; unpublished Chubb Lecture, Yale University, September 26, 2007.

31. Peter Donovan, “The Intolerance of Religious Pluralism,” Religious Studies 29 (1993).

32. For a related case, see Broward Listow's article on missionary work in the immediate aftermath of the Iraqi invasion, Time, April 15, 2003. www.time. com/time/world/article/0,8599,443800,00.html.

33. Uma Narayan, Dislocating Cultures: Identities, Traditions, and Third-World Feminism (New York: Routledge, 1997), 81-118.

34. I am aware of the problematic of using this term, which was created through the overdetermined discourse of the West. While I use the term third world for ease of reference, I acknowledge it as highly problematic. As Chandra Talpade Mohanty notes ("Under Western Eyes"), "only from the vantage point of the West is it possible to define the 'third world' as underdeveloped and economically dependent. Without the overdetermined discourse that creates the third world, there would be no (singular and privileged) first world. Without the 'third-world woman,' the particular self-presentation of western women ... [as progressive, liberated, superior] ... would be problematical." See Chandra Talpade Mohanty's essay "Under Western Eyes: Feminist Scholarship and Coioniai Discourses," available at: http://blog.lib.umn.edu/raim0007/RaeSpot/ under\%20wstrn\%20eyes.pdf, 353, accessed January 15, 2009. Also see her Feminism without Borders: Decolonizing Theory, Practicing Solidarity (Durham, NC: Duke University Press, 2003).

35. See Narayan, Dislocating Cultures, 86.

36. TMTC Newsletter (a publication of the Toronto Mennonite Theological Centre) 11 , no. 1 (summer 2003): 1 and 4.

37. See Mohammad Ali Amir-Moezzi, The Divine Guide in Early Shi ism: The Sources of Esotericism in Islam, trans. David Streight (Albany: State University of New York Press, 1994); also see a more recent study of this issue by Liyakat N. Takim, The Heirs of the Prophet: Charisma and Religious Authority in Shi ite Islam (New York: State University of New York Press, 2007).

38. C. M. Naim, "Some Thoughts on Christian Muslim Dialogues," in Ambiguities of Heritage: Fictions and Polemics (Karachi: City Press, 1999), 189-90, quoted in Marcia Hermansen, "Muslims in the Performative Mode: A Reflection on Muslim-Christian Dialogue," The Muslim World 94 (2004): 391. 
39. For example, my request to present a contending paper at the 2007 conference was refused and the protesters to the terms of that dialogue/conference were shut out.

40. The shroud of quasi-secrecy that characterizes this decade-long private dialogue exacerbates the situation. I was asked by the Mennonites involved, in emphatic terms, not to publicize the May 2007 University of Waterloo conference for fear of a backlash from the Canadian-Iranian community.

41. TMTC Newsletter 11, no. 1 (summer 2003): 14. Surprisingly, Iran is not noted.

42. Narayan, Dislocating Cultures, 100.

43. TMTC Newsletter 11, no. 1 (summer 2003): 1; Or consider: "Building Bridges: The Shi a of Iran and Mennonites of North America," which is the title of a piece by Ed Martin in Mennonite Central Committee's Peace Office Newsletter 36, no. 1 (Jan.-Mar. 2006), 1.

44. TMTC Newsletter 11, no. 1 (summer 2003): 1.

45. Mesbah-Yazdi and his organization can strike fear into the hearts and exact vengeance on those who oppose his views anywhere in the world.

46. Thomas Finger, "Demonization and Dialogue," Anabaptist-Mennonite Scholars Network Newsletter 11, no. 2 (fall 2008): 10.

47. Ibid., 11.

48. Iran's nuclear ambitions are often viewed in a geopolitical context. Hardly any attention is paid to the Shi $\mathrm{i}$ popular culture that fuels its messianic narrative and the complex ways it is exploited by Ahmadinejad. Therefore, as a foreigner who spent a few days in Iran and talked several times with Ahmadinejad, Finger can be forgiven for making sweeping simplifications. I have argued at length about this specifically Shi i dimension of current Iranian politics in my unpublished paper: "The Shi'i Messianic Imperative and the Nuclear Bomb: Ahmadinejad's Nuclear Ambition in the Context of Iran's Shi i Popular Culture," presented at the American Academy of Religion - Eastern International Regional Meeting, May 4-5, 2007, University of Waterloo and Wilfred Laurier University, Waterloo, ON, Canada.

49. Homi Bhabha, The Location of Culture (New York: Routledge, 1994), 74-75.

50. Jean Laplanche and Jean-Bertrand Pontalis, The Language of Psychoanalysis, trans. Donald Nicholson-Smith (London: Hogarth Press and the Institute of Psycho-Analysis, 1973), 118.

51. Bhabha, The Location of Culture, 75.

52. Ibid.

53. Presented by an IKERI representative at the 2002 Toronto conference. Reported in TMTC Newsletter 11, no. 1 (summer 2003): 5. In that paper, Hamid Parsania identifies eighteen different types of reason.

54. Jewel Showalter, "Dialogue and Witness: Topic One, Precious Friendships in the Middle East," in Anabaptists Meeting Muslims: A Calling for Presence in the Way of Christ, ed. J. R. Krabill, D. W. Shenk, and L. Stutzman (Scottsdale, PA and Waterloo, ON: Herald Press, 2005), 330. 
55. Lori E. Amy, "Contemporary Travel Narratives and Old Style Politics: American Women Reporting after the Gulf War," Women Studies International Forurm 22, no. 5 (1990): 536.

56. I was also present at that meeting.

57. Some of the participants felt an uncanny similarity between Mesbah-Yazdi's and the MCC's theological justification for their positions.

58. Sigmund Freud, "Fetishism" (1927), in his On Sexuality, ed. Angela Richards (Harmondsworth: Penguin, 1977), 351-57; also see "Editor's Note," 347-49.

59. Karl Marx, Das Kapital (Washington, DC: Regnery Publishing, Gateway Editions, 2000), chapter 1, section 4, "The Fetishism of Commodities and the Secret Thereof," 50-62.

60. Georg Lukács, The Historical Novel (Lincoln: University of Nebraska Press, 1983), 83

61. Susan Kennel Harrison, "Journeying Together," Anabaptist-Mennonite Scholars Network Newsletter 11, no. 2 (fall 2008): 4.

62. In all fairness, it is highly unlikely that the MCC can simply change its dialogue partner. It is no coincidence that IKERI was put forth by the Iranian regime as the one and only partner in this dialogue. With the official and unofficial structures of power at its disposal, and considering that IKERI exploits this dialogue as an important source to gain legitimacy within Iran, the MCC cannot bypass it and establish new relationships with another organization.

63. See Deleuze and Guattari's articulation of the difference between a tracing and a map in Gilles Deleuze, Felix Guattari, and Brian Massumi, A Thousand Plateaus: Capitalism and Schizophrenia (Minneapolis: University of Minnesota Press, 1988), 12-15.

64. This is particularly surprising, considering that in other parts of the Middle East the MCC has the political astuteness of focusing on people left out of the society's power structure. For example, see www.mcc.org/about/peacecommitment/practice.html, accessed January 15, 2009.

65. For example, see Kennel Harrison, "Journeying Together," 4-6; and Jon Hoover, "Searching for Words: A Personal Journey through the Shi iMennonite Dialogues," Anabaptist-Mennonite Scholars Network Newsletter 11, no. 2 (fall 2008): 7. 